www.jmscr.igmpublication.org

Impact Factor 5.84

Index Copernicus Value: 83.27

ISSN (e)-2347-176x ISSN (p) 2455-0450

crossref DOI: _https://dx.doi.org/10.18535/jmscr/v5i6.13

Journal Of Medical Science And Clinical Research

\title{
Study of Pulmonary Function Tests in Chronic Smokers and Alcoholic Males
}

Authors

\author{
Mrs. Anita Jain ${ }^{1}$, Dr Keerti Mathur ${ }^{2}$, Dr Manisha Sankhla ${ }^{3}$ \\ ${ }^{1} \mathrm{PhD}$ Scholar, ${ }^{2}$ Senior Professor, ${ }^{3}$ Senior Demonstrator \\ Department of Physiology, S.M.S. Medical College, Jaipur (Rajasthan)
}

Corresponding Author

Mrs. Anita Jain

Department of physiology, S.M.S. Medical College, Jaipur- 302004 (Rajasthan)

Email:dr.anita17sep@yahoo.in

\begin{abstract}
Background \& Objectives: Major health risks are caused by alcohol and tobacco whenever used alone or together. Assessment of pulmonary function is important investigation because early detection of functional impairment and its appropriate treatment will help in decreasing morbidity and mortality related to disease. The aim of the present study is to measure and compare pulmonary function tests such as FVC, FEV, FEV $/$ I FVC \%, PEFR and MVV between study groups (smoker, alcoholic, smoker with alcoholic) and control group. The present study involved 360 subjects in the age group of 30-60 years, both smoker and alcoholic, recruited from medicine OPD from S.M.S. Hospital, Jaipur (Rajasthan). Out of total 360 subjects: - 90 were smoker, 90 were alcoholic, 90 were smoker with alcoholic and 90 were control subjects. Data were statistically analyzed by student's unpaired ' $t$ ' test, one way ANOVA and post hoc tukey test. All pulmonary function tests such as FVC, FEV, FEV / FVC \%, PEFR and MVV were decreased in smokers (group - B) when compared to control and alcoholic subjects and it was found to be decreased further when associated with alcohol consumption (smoker with alcoholic subjects). Results were statistically significant $(p<0.05)$. Smoking alone and together with consumption of alcohol causes decrease in pulmonary functions mainly FVC, FEV,$F E V_{l} / F V C$ ratio, PEFR and MVV, suggesting both obstructive and restrictive type of respiratory diseases.

Keywords: Forced Vital Capacity [FVC (L)], Forced Expiratory Volume in one Second [ FEV $(L)]$, Peak Expiratory Flow Rate [ PEFR (L/Min)], Maximum Voluntary Ventilation [ MVV (L/Min)]
\end{abstract}

\section{INTRODUCTION}

In India, tobacco consumption continues to increase, even though the evidences mount about its hazards. A latest study about fatality related to smoking in India (2008), estimated that at least 9,30,000 adult deaths (in India) can be caused due to smoking, and this would increase annually more than one million from $2010^{(1)}$. Risk of many types of cancers, heart disease, strokes and emphysema has increased in smokers ${ }^{(2)}$.

Alcohol is also extensively used in modern society (3). Ethanol affects many organ system of the body, by causing alteration in the functions of membrane proteins in different cells of gastrointestinal tract, urinary tract, cardiovascular and nervous system ${ }^{(4)}$. Scientist suggested that 
adverse affect will be precipitated by a minimum of $100 \mathrm{ml}$ of ethyl alcohol per day for 5 years ${ }^{(5)}$. Alcohol is consumed mostly in the form of ethanol but it is consumed in different forms also, containing different concentrations of alcohol such as - Beer (4\% - 12\%), Wine (10\% - 15\%), Rum $(37.5 \%-75 \%)$, and Whisky $(40 \%-55 \%)^{(6)}$. The aim of the present study was to measure and compare pulmonary function tests between study groups (smoker, alcoholic, smoker with alcoholic) and control group.

\section{MATERIAL AND METHODS}

The present study involved 360 males attendants (30-60 years) of patients recruited from medicine OPD from S.M.S Hospital, Jaipur. Subjects were divided into 4 groups and each group contains 90 males:-

Group (A) - control (non-alcoholic and nonsmoker)

Group (B) - smoker

Group (C) - alcoholic

Group (D) - alcoholic with smoker

Statistical analysis: The mean values of all variables (pulmonary functions) were compared by using one way ANOVA and post hoc tukey test. Results were presented as Mean \pm SD. All the statistical analysis were performed using SPSS for windows Version 23 and Microsoft Excel 2007, using appropriate software, $\mathrm{p}$ value $<0.05$ was taken as significant.

The subject (group - B, C, D) smokers (in terms of pack years) and alcoholic (according to safe units of alcohol consumption) for more than 10 years were selected for the study.

Pack year (unit that determines the number or total a person has smoked over a long period of time) was calculated by multiplying the number of packs of cigarettes smoked per day with the number of years a person has smoked.

Pack years $=($ packs of cigarettes smoked per day $)$ $\times$ (number of years as a smoker) [(1 pack has 20 cigarettes $)^{(7) \text {. }}$
Alcoholics were selected according to safe units of alcohol as:

Units of alcohol were calculated as follows:-

Unit $=$ Volume of drink $\times \mathrm{ABV}$ (alcohol by volume or $\%$ of alcohol $) \div 1000$

Institutional ethical committee clearance was obtained before starting the study. An informed consent was taken from all the subjects after explaining the study. All the parameters were measured after 24 hours of drinking alcohol ${ }^{(8)}$.

Exclusion criteria: Subjects suffering from any acute and chronic illness, fasting, practicing meditation or yoga therapy or on placebo treatment and having any visual or auditory problem were excluded from the study.

\section{Measurement of Different Parameters}

Each group was evaluated for different parameters such as - Height $(\mathrm{cm})$ and weight $(\mathrm{kg})$, blood pressure (mmHg):- by sphygmomanometer, Pulmonary function tests: - Forced Vital Capacity [FVC (L)], Forced Expiratory Volume in one Second $\left[\mathrm{FEV}_{1}(\mathrm{~L})\right]$, FEV1 / FVC \%, Peak Expiratory Flow Rate [PEFR (L / Min)], Maximum Voluntary Ventilation [MVV (L / Min)]

\section{Measurement of Pulmonary Function Tests: -}

Pulmonary function tests were assessed using spirometer, which measures inspiratory and expiratory parameters. It is a computerized spirometer designed for performing pulmonary functions. This instrument is used with the electrochemical pneumotach transducer supplied with the instrument.

Before starting the process, the procedure was explained and demonstrated to each subject. The mouthpiece was placed in subject's mouth in such a manner that effective air seal was obtained with the lips and no obstruction was caused by tongue or teeth, then subject was asked to have a forceful inspiration, (with the help of nose clip nose was closed) and then to blow in the mouthpiece of spirometer with maximum and quick expiration till complete emptying of lung. Various 
pulmonary functions which were measured and compared in study (smoker, alcoholic, smoker with alcoholic) and control group using spirometer were -

\section{Forced vital capacity [FVC (L)]}

2. Forced expiratory volume in one second $\left[\mathrm{FEV}_{1}(\mathrm{~L})\right]$

3. $\mathrm{FEV}_{1} / \mathrm{FVC}$ ratio

4. Peak expiratory flow rate [PEFR (L/ min.]

5. Maximum Voluntary Ventilation [MVV (L/ min.)]

These parameters were measured and compared in study (smoker, alcoholic, smoker with alcoholic) and control group (non-alcoholic and non-smoker) subjects to assess the effect of alcohol and smoking on pulmonary functions.

\section{RESULTS}

In the present study the mean $\pm \mathrm{SD}$ values of age (years) for control group and study group were $43.03 \pm 9.42$ and $43.1 \pm 10.76$, respectively. The mean \pm SD values of BMI $\left(\mathrm{kg} / \mathrm{m}^{2}\right)$ for control group and study group were $23.78 \pm 3.98$ and $23.47 \pm 3.75$, respectively. The mean $\pm \mathrm{SD}$ values of SBP $(\mathrm{mmHg})$ were $123.96 \pm 6.86$ and $125.11 \pm 7.64$, DBP $(\mathrm{mmHg}): 84.49 \pm 6.04$ and $85.24 \pm 7.15$ and MBP (mmHg): $97.64 \pm 5.9$ and $98.53 \pm 6.94$ for control group and study group, respectively. All the values were within normal range and nonsignificant (students unpaired ' $t$ ' test).

Table 1: Comparison of Pulmonary Function Tests in control and study group subjects

\begin{tabular}{|c|c|c|c|c|c|c|}
\hline S. No. & Parameters & Groups & $\mathrm{N}$ & Mean & $\begin{array}{c}\text { Standard } \\
\text { Deviation }\end{array}$ & $\mathrm{p}$ value \\
\hline \multirow[t]{4}{*}{1.} & \multirow[t]{4}{*}{ FVC (L) } & Control & 90 & 3.50 & 0.76 & \multirow{4}{*}{$0.0000^{*}$} \\
\hline & & Smoker & 90 & 2.85 & 0.81 & \\
\hline & & Alcoholic & 90 & 3.32 & 0.75 & \\
\hline & & Smoker\& Alcoholic & 90 & 2.79 & 1.00 & \\
\hline \multirow[t]{4}{*}{2.} & \multirow[t]{4}{*}{$\mathrm{FEV}_{1}(\mathrm{~L})$} & Control & 90 & 3.02 & 0.67 & \multirow{4}{*}{$0.0000 *$} \\
\hline & & Smoker & 90 & 2.33 & 0.80 & \\
\hline & & Alcoholic & 90 & 2.77 & 0.70 & \\
\hline & & Smoker\& Alcoholic & 90 & 2.31 & 1.00 & \\
\hline \multirow[t]{4}{*}{3.} & \multirow[t]{4}{*}{$\mathrm{FEV}_{1} / \mathrm{FVC}$ ratio } & Control & 90 & 0.86 & 0.07 & \multirow{4}{*}{$0.0028 *$} \\
\hline & & Smoker & 90 & 0.80 & 0.14 & \\
\hline & & Alcoholic & 90 & 0.83 & 0.11 & \\
\hline & & Smoker\& Alcoholic & 90 & 0.80 & 0.13 & \\
\hline \multirow[t]{4}{*}{4.} & \multirow[t]{4}{*}{ PEFR (L /min.) } & Control & 90 & 432.50 & 101.94 & \multirow{4}{*}{$0.0000 *$} \\
\hline & & Smoker & 90 & 320.88 & 133.59 & \\
\hline & & Alcoholic & 90 & 400.92 & 121.51 & \\
\hline & & Smoker\& Alcoholic & 90 & 324.90 & 141.22 & \\
\hline \multirow[t]{4}{*}{5.} & \multirow[t]{4}{*}{ MVV (L /min.) } & Control & 90 & 124.98 & 15.62 & \multirow{4}{*}{$0.0000 *$} \\
\hline & & Smoker & 90 & 94.87 & 20.20 & \\
\hline & & Alcoholic & 90 & 96.06 & 24.59 & \\
\hline & & Smoker\& Alcoholic & 90 & 87.50 & 20.71 & \\
\hline
\end{tabular}

$(\mathrm{N}=$ no. of subjects $)(\mathrm{p}<0.05, \text { significant })^{*}$ 
By using One-way ANOVA, a statistically significant difference was observed in mean values of $\mathrm{FVC}(\mathrm{L}), \mathrm{FEV}_{1}$ (L), $\mathrm{FEV}_{1} / \mathrm{FVC} \%$, PEFR (L/min.), MVV (L / min.) between control and study groups. After applying Post hoc tukey test, statistically significant difference was observed for FVC (L) and PEFR (L/min.) between group A \& B, A \& D, B \& C and C \&D, for $\mathrm{FEV}_{1}$ (L) between $\mathrm{A} \& \mathrm{~B}, \mathrm{~A} \& \mathrm{C}, \mathrm{A} \& \mathrm{D}, \mathrm{B} \& \mathrm{C}$ and $\mathrm{C}$ $\& \mathrm{D}$, for $\mathrm{FEV}_{1} / \mathrm{FVC} \%$ between $\mathrm{A} \& \mathrm{~B}$ and $\mathrm{A} \&$ $\mathrm{D}$, for MVV (L/ min.) between A \& B, A \& C, A $\& \mathrm{D}, \mathrm{B} \& \mathrm{D}$ and $\mathrm{C} \& \mathrm{D}$.

\section{DISCUSSION}

Cigarette smoking has extensive effects on the respiratory functions and smoking is the main cause of a number of respiratory diseases, mainly chronic bronchitis, emphysema and bronchial carcinoma ${ }^{(9)}$.

Measurable feedback about the function of the lungs is provided by non-invasive diagnostic tests known as pulmonary function tests. These tests provide specific information for clinical diagnosis and research purpose by assessment of lung volumes, capacities and flow rates ${ }^{(10)}$. Assessment of pulmonary function is important investigation because early detection of functional impairment and its appropriate treatment will help in decreasing to reduce morbidity and mortality related to disease ${ }^{(11)}$.

In the present study there was statistically no significant difference in the mean values of age, height, weight, body mass index, systolic blood pressure, diastolic blood pressure and mean blood pressure between control and study groups, thereby showing proper matching of controls and study group subjects. So these groups (study and control) are comparable for the study.

In this study, smokers (group - B) have least pulmonary function tests $\left[\mathrm{FVC}(\mathrm{L}), \mathrm{FEV}_{1}(\mathrm{~L})\right.$, $\mathrm{FEV}_{1}$ / FVC\%, PEFR (L/min.), MVV (L / min.)] as compared to control and alcoholic subjects which were further decreased in smoker with alcoholic subjects. Decrease in $\mathrm{FEV}_{1}$, PEFR and other flow rates indicated obstructive pulmonary impairments and fall in FVC indicated about restrictive pulmonary impairments.

Thus present results are comparable with the findings of Buktar L et al (2015) ${ }^{(12)}$, Phatale SR and Boramma S (2014) ${ }^{(13)}$, Jerusha J and Santhi V (2014) ${ }^{(14)}$, Mistry A et al (2014) ${ }^{(15)}$, Nawafleh $\mathrm{AH}$ et al (2012) ${ }^{(16)}$, Nighute $\mathrm{S}$ and Awari A $(2011)^{(9)}$.

In this study pulmonary function was found to be decreased further when smoking is associated with alcohol consumption. Chronic consumption of alcohol along with smoking thus affects pulmonary functions and causes both restrictive and obstructive type of respiratory diseases. The probable reason for this may be as follows: The surface of tracheo-bronchial tree is covered with ciliated and mucus producing cells ${ }^{(17)}$. Alcohol limits the transport of carbon particles which are trapped in mucous layer overlying the cilia which provide first line of defense mechanism against particulate air pollutant ${ }^{(18)}$. The ciliary motion is affected by the chemical factors but only at high concentration of alcohol in blood.

The cleansing function of the tracheo-bronchial tree and defense against pathogens is provided by alveolar macrophages. Migration of these phagocytic cells is slowed down by alcohol that causes decrease bacterial capacity, due to insufficient macrophage mobilization ${ }^{(19)}$. Due to increase exposure to alcohol the bactericidal capacity of these cells is depressed, which is normally accentuated ${ }^{(20)}$.

\section{CONCLUSION}

Smoking alone and together with consumption of alcohol causes decrease in pulmonary function mainly FVC, $\mathrm{FEV}_{1} / \mathrm{FVC}$ ratio and PEFR, significantly, and causes both restrictive and obstructive types of pulmonary diseases.

\section{REFERENCES}

1. Lal PG, Wilson NC, Gupta PC. Attributable deaths from smoking in the last 100 years in India. Curr Sci 2012; 
103:1085-90. Last Reviewed on 03/08/2013.

2. Lal S, Adarsh P. Textbook of community medicine. $2^{\text {nd }}$ edition New Delhi; CBS 2009: 597-598.

3. Kirschstein R, Shalala DE. Department of Health and Human Services. Tenth $\left(10^{\text {th }}\right)$ special report to the U.S. Congress on alcohol and health 2000:13.

4. Estruch R, Nicolas JM. Alcohol, alcohol abuse and alcoholism. 1993; 28 (5): 543550.

5. Fiona B, Andrew RT. Neuropathy in an alcoholic population Postgraduate Medical Journal 1987; 63: 1033-1036.

6. Morse RM, Flavin DK. "The definition of alcoholism. The joint committee of the National Council on Alcoholism and Drug Dependence and the American Society of Addiction Medicine to study the definition and criteria for the Diagnosis of Alcoholism." The Journal of American Medical Association 1992; 268 (8): 10121014.

7. Sabia S, Marmot M, Dufouil C, SinghManoux A. Smoking history and cognitive function in middle age from the Whitehall II study. Archives of Internal Medicine 2008; 168:1165-1173.

8. Laurence LB, John SL, Parker K. Goodman \& Gilman's, The Pharmacological Basis of Therapeutics $11^{\text {th }}$ edition 2006: 591-606.

9. Nighute S, Awari A. A study of pulmonary function tests among smokers and nonsmokers in a rural area of Gujarat. Journal of Clinical and diagnostic research 2011 Nov.; 5(6) :1151-1153.

10. Cotes JE, Chinn DJ, Miller MR. Lung function: Physiology, measurement and application in medicine. Blackwell publishing, Fourth edition, 1979.
11. Madan D, Singal P, Kaur H. Spirometric evaluation of pulmonary function tests in bronchial asthma patients. Journal of exercise science and physiotherapy 2010; 6(2): 106-111.

12. Buktar L, Jagtap A, Ansari H. Pulmonary function tests in chronic alcoholics. Indian Journal of Basic and applied medical research $2015 \mathrm{Sep}$; 4(4):673-677.

13. Phatale SR, Boramma S.The study of pulmonary function tests in chronic alcoholics. International Journal of recent trends in sciences and technology, 2014; 10 (1):01-03.

14. Jerusha J, Santhi V. Comparative study of pulmonary function tests in smokers and non-smokers. Buletin of pharmaceutical and medical sciences (BOPAMS) 2014; 2(2):2201-2208.

15. Mistry A, Tyagi R, Kagathara J, Vaidya L, Dholakiya U, Shah C. Comparative study of pulmonary function tests in smokers and non-smokers. GCSMC J Med Sci 2014 Jan-June; 3(1): 22-27.

16. Nawafleh HA, Abo-zead S AL-S, AlMaghalreh DF. Pulmonary Function Test: The value among smokers and nonsmokers. Health science journal 2012 oct.dec. ; 6(4) :703-713.

17. Heinemann HO. Alcohol and the lung-A brief review, Am.J.Med.1977; 63:81-84.

18. Green GM. Pulmonary clearance of infection agents. Ann. Rev. Med. 1968; 19: 315 .

19. Kilburn KH. Cilia and mucus transport as determinants of the response of lung air pollutants. Arch. Environ Health, 1967; 14: 77.

20. Grenn GM, Kass EH. The influence of bacterial species in pulmonary resistance to infection in mice subjected to hypoxia, cold stress and ethanolic intoxication. Br. Journal of Exp. Pathol 1965; 46:360. 